\title{
ISOLATION AND CHARACTERIZATION OF TWO IMPORTANT HONEYBEE-KILLING VIRUS SPECIES, DEFORMED WING VIRUS (DWV) AND BLACK QUEEN CELL VIRUS (BQCV) FROM MESSOR CONCOLOR ANTS (HYMENOPTERA: FORMICIDAE)
}

\author{
RÜSTEMOĞLU, M. \\ Şırnak University, Faculty of Agriculture, Plant Protection Department \\ 73300 Idil/Şırnak, Turkey \\ e-mail: mustafa.rustemoglu@gmail.com; phone: +90-486-551-30-32
}

(Received $18^{\text {th }}$ Jun 2020; accepted $16^{\text {th }}$ Sep 2020)

\begin{abstract}
Pathogenic organisms such as viruses can infect multiple host species from different trophic levels. Honeybee, A. mellifera is naturally infected by many viruses. Understanding the mechanism underlying virus spread in honeybee colonies highly depends on the pathogenic ability of honeybee killing viruses in other insects such as ants, Messor concolor (Hymenoptera: Formicidae). The purpose of this study was to investigate the existence and prevalence of two significant viruses, deformed wing virus (DWV) and black queen cell virus (BQCV) of honeybees in ants from the nests around different honeybee apiaries in Southeast Turkey by using reverse transcription polymerase chain reaction (RT-PCR). Both viruses were present in two nests while the former existed in another hive. Some ant nests were uninfected. This study is the first to report the molecular detection of the honeybee infecting DWV and BQCV in ants. Further studies should be devoted to the mechanisms underlying virus spread between honeybee and other interacting insects especially the Hymenopterans.
\end{abstract}

Keywords: honeybee virus, new host, foodborne transmission, Southeast Turkey

\section{Introduction}

Insects are host to a wide range of viruses that have significant effects on their nature. Honeybee viruses are probably the best-known insect viruses due to important economic losses (Smith et al., 2013; McMenamin and Genersch, 2015). Presence of more than twenty different virus species infecting honeybee, most of which are single-stranded positive RNA viruses, have been reported so far (de Miranda et al., 2013). Understanding the transmission mechanism of honeybee viruses in a hive and apiary is necessary to reveal population dynamics of bee viruses as an important threat. The deformed wing virus (DWV) (Iflaviridae) and black queen cell virus (BQCV) (Dicistroviridae) are the most commonly found virus species (de Miranda et al., 2013).

Deformed wing virus (DWV) is probably the most commonly encountered virus species infecting honeybees (Bailey and Ball, 1991; Lanzi et al., 2006; Berényi et al., 2007). Deformed wing, shortened abdomens, discoloring, and a decrease in the life span of bees are the clinical indicators noticed under heavy DWV infection. Deformed wing virus infection mostly does not result in clear symptoms when transmitted by other vectors than the ectoparasitic mite, Varroa destructor (Mesostigmata: Varroidae) (de Miranda and Genersch, 2010). DWV transmits both vertically and horizontally and also isolated from all cast (Queen, Drone, Worker) and life stage (egg, larva, pupae, and adult) of honeybee. Commercial and wild bumble bees can be infected by DWV. Bombus terrestris and Bombus pascorum shows wing deformities, (Genersch et al., 2006), and serology in Apis cerana and Apis florea (Allen and Ball, 1996; Ellis and Munn, 2005). DWV was also recorded in other insects such as small hive beetle, Aethina tumida (Coleoptera; 
Nitidulidae) and the wax moth, Galleria mellonella (Lepidoptera: Pyralidae) which are in interaction with honeybee (Eyer et al., 2009; Traiyasut et al., 2016).

BQCV, one of the most common honeybee virus, multiplies in adult bees, particularly when ingested with the microsporidian parasite spores Nosema apis (Bailey et al., 1983; Tapaszti et al., 2009). The infection ability of these viruses is not restricted to A. mellifera. Previous reports indicated that wild species of bees, Apis dorsata and A. florea (Zhang et al., 2012), and B. terrestris (Choi et al., 2015) were also infected by DWV and BQCV. Understanding and monitoring the global dispersal of DWV and BQCV are crucial for predicting their epidemy and successfully controlling the aforementioned viruses (Freiberg et al., 2012). Previous studies revealed presence of some honeybee viruses infecting other Arthropoda and, especially, ant species. For example, the earliest bee virus detected in an ant species (Camponotus vagus) is the chronic bee paralysis virus (CBPV) which is both viral and replicative (Celle et al., 2008). In another study, beside BQCV and DWV, some other viruses such that Israeli acute paralysis virus (IAPV), Kashmir bee virus (KBV), and sacbrood virus (SBV) were detected in the species of 11 non-Apis hymenoptera and pollen pellets of forager bees (Singh et al., 2010). Further research approved the existence of honeybee viruses in some ant species such as Camponotus sp. and Tetramorium caespitum (Levitt et al., 2013). In addition, the Argentine ant (Linepithema humile) was also reported being infected by DWV, BQCV, and KBV (Gruber et al., 2017). Moreover, Lake Sinai viruses (LSVs) were detected in Messor concolor, M. capitatus and M. barbarous (Bigot et al., 2017). Caged ants (Myrmica rubra) fed with infected A. mellifera pupae can be infected by DWV (Schläppi et al., 2019). In total, 57 samples belonging to 13 different ant genera collected in apiaries were analyzed and $51(89 \%)$ of the samples were found infected at least by one of the following honeybee viruses; DWV, BQCV, IAPV, SBV, KBV, and Acute bee paralysis virus (ABPV) (Payne et al., 2020).

During routine surveys, I found that infected honeybee individuals were taken by ants to their nests which could be a possible route of transmission for honeybee infecting viruses from bees to ants. Thus, the aim of this study was first to demonstrate whether two important honeybee infecting viruses, BQCV and DWV exist in M. concolor. Further, the genome variability of a partial sequence of DWV and BQCV were evaluated.

\section{Material and Methods}

\section{Survey}

Samples from 7 ant nests were collected from Southeast Turkey (Hakkari and Şırnak provinces), in June 2016 (Figure 1). From each nest, four ant samples were collected. This samples were placed in a freezer at $-80{ }^{\circ} \mathrm{C}$ till the laboratory analysis. The collected samples were transported to the laboratory for diagnostic studies and RNA isolations. Samples were stored in $70 \%$ ethyl alcohol for diagnosis at -80 for RNA isolation.

\section{RNA extraction}

For preparing homogenates from ant samples, liquid nitrogen was used in a sterile mortar. All homogenized ant samples were placed into the sterile Eppendorf tubes. The RNA was prepared using a modified silica-capture method (Foissac et al., 2001). Four ants $(M$. concolor) were extracted for each ant nest. Total RNA was resuspended in free RNases and DNases water and kept at $20^{\circ} \mathrm{C}$ temperature. Total RNAs were placed in a freezer at $-20^{\circ} \mathrm{C}$ till for laboratory analysis. 


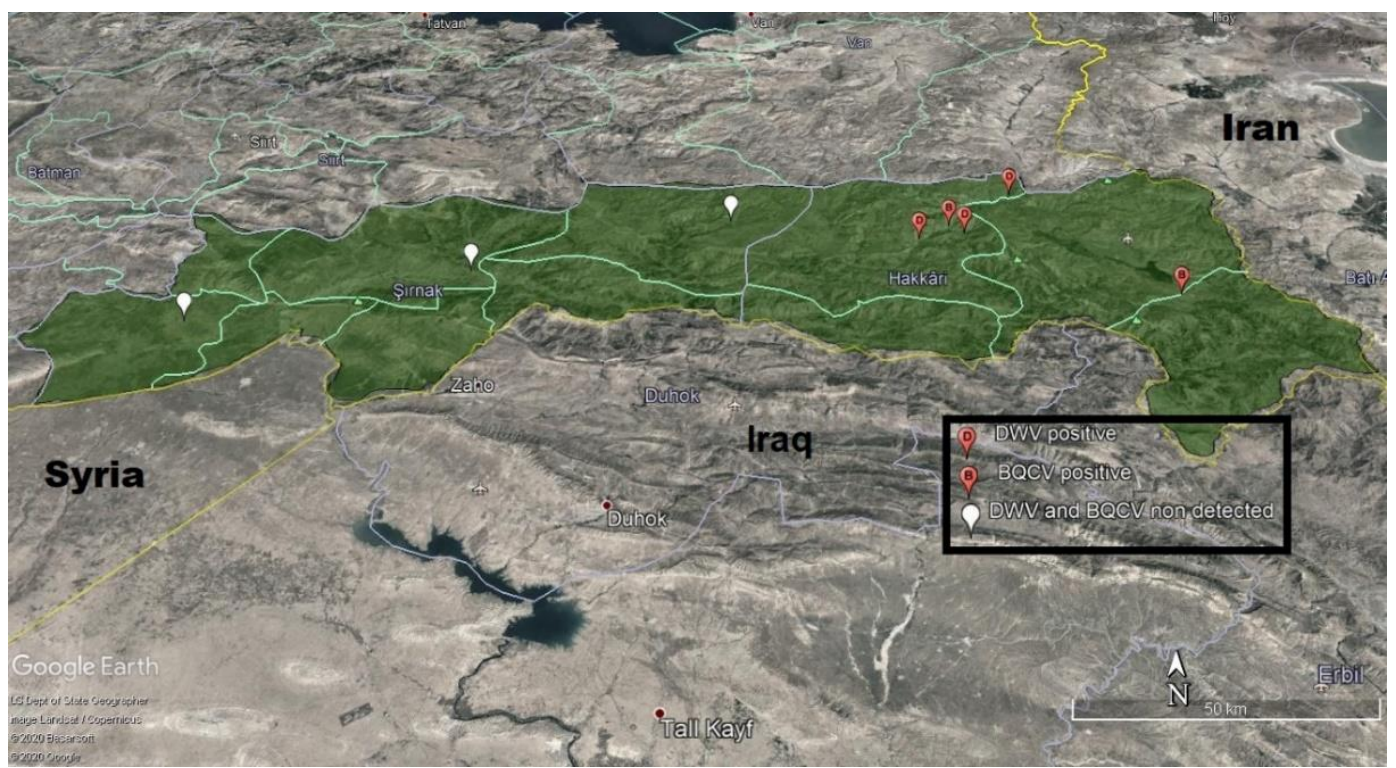

Figure 1. The map of the collected ant sample is the green area. Each symbol shows the initial letter of the virus isolated from the collected ant sample

\section{RT-PCR of CP and RdRp genes}

The DWV and BQCV viruses were detected using the procedure described in Rüstemoğlu and Sipahioğlu (2019). Genome-specific primers amplifying the $488 \mathrm{bp}$ and 567 bp fragments of RNA depended RNA polymerase (RdRp) and partial coat protein (CP) genes were characterized by molecular cloning and sequencing for DWV and BQCV, respectively. The reverse transcription polymerase chain reaction was performed using a purified RNA from the RevertAid First Strand cDNA kit in accordance with the instruction of the producer company (Vilnius, Thermo-Fermentas Lithuania). The final volume was completed to $25 \mu \mathrm{l}$ for PCR reaction. The solution comprised of $2.5 \mu \mathrm{l}$ of $10 \times$ reaction buffer $(200 \mathrm{mM}$ Tris $-\mathrm{HCl} \mathrm{pH}$ of 8.4 and $500 \mathrm{mM} \mathrm{KCl}), 1 \mu 1$ of cDNA, $0.5 \mu \mathrm{l}$ of dNTPs $\left(20 \mathrm{mM}\right.$ each), $1.5 \mu \mathrm{l}$ of $\mathrm{MgCl}_{2}(25 \mathrm{mM}), 0.5 \mu \mathrm{L}$ of each primer $(100 \mathrm{pmol}), 0.2 \mu \mathrm{L}$ of Taq DNA polymerase and $18.3 \mu \mathrm{l}$ of nuclease free water. Following, the partial $\mathrm{CP}$ and $\mathrm{RdRp}$ gene were amplified using thermal cycling diagram in a RT-PCR. The thermal cycle diagram was as follow; 2 minutes 35 cycles in a minute at $94{ }^{\circ} \mathrm{C}$ temperature, 30 seconds at $57^{\circ} \mathrm{C}$ temperature, 45 seconds at $72{ }^{\circ} \mathrm{C}$ temperature and finally incubated for 10 minutes at $72{ }^{\circ} \mathrm{C}$ temperature. The amplified products at the end of the thermal cycling were separated using $1.5 \%$ agarose gel and stained with ethidium bromide to visualize (Sambrook et al., 1989).

\section{Molecular cloning and sequencing}

The virus isolates identified were cloned and sequenced separately. The isolation of amplified pieces was carried out in $1 \%$ agarose gel and recovered by using a GeneJET Gel Extraction Kit based on the prescription provided by the producer company (Thermo Scientific). The pGEM ${ }^{\circ}-\mathrm{T}$ Easy vector (Promega) was used to purify the DNA fragments. The plasmid was employed to turn competent cells of Escherichia coli JM 109 to ampicillin resistance using electroporation (BioRad, USA). Blue-white selection on $\mathrm{X}$-gal medium plate was used to choose the transformants harboring the DNA of 
DWV-Ant-1 and BQCV-Ant-1 isolate and a colony PCR was employed to screen as positive clones. One clone, named DNA of DWV-Ant-1 and BQCV-Ant-1 was selected for the sequencing of DNA. Automated DNA sequences of Refgen Research and Biotechnology Company (İstanbul, Turkey) was used in sequencing the clones of cDNA.

\section{Phylogenetic analysis}

The sequences of DWV and BQCV used in comparisons were procured from the database of Genbank. The unreleased isolates for Turkish sequences of DWV and BQCV isolates were also used in the phylogenetic analysis. Multiple sequence alignments and phylogenetic reconstructions were performed for sequence similarity and phylogenetic analysis using the software of CLC Main Workbench and MEGA-X (Kumar et al., 2018). The stability of phylogenies was deduced by 1000 bootstrap replication using the method of maximum likelihood described in Tamura and Nei (1993).

\section{Results}

PCR results indicated that DWV (3/7) and BQCV (2/7) were found in the $M$. concolor nests (Figure 2). All positive samples were detected within the borders of Hakkari province (Figure 1). The sequence of DWV (GenBank Accession No. MT831948) isolates obtained from surveys had \%99-95 similarity when compared with other DWV isolate records from different countries. The DWV sequence obtained from this study shows the most nucleotide similarity with KX373900.1 (France) (99.02\%), MH267695.1 (Sweden), KT215905.1 (United Kingdom), KF840795.1 (Lithuania), HM067438.1 (United Kingdom) (98.77\%) and KP835214.1 (Turkey), KF840794.1 (Lithuania), (98.53\%) isolates, respectively. The BQCV sequence (GenBank Accession No. MT338252) obtained indicated the highest similarity to four isolates MK431882.1 (99.78\%), MK431880.1 (99.10\%), MK431881.1 (98.65\%) and KP835213.1 (98.24\%), respectively. These four BQCV isolates were obtained from A. mellifera in Turkey (Hakkari and Muğla). Besides these four isolates in the phylogenetic tree, BQCV (M. concolor) was clustered in a common branch with South Korean isolates JQ434132.1 (Ac), KP835213.1 (Am) and JQ434135.1 (Am). Phylogenetic trees were used to illustrate the relationships between the sequences. The phylogenetic trees were constructed with the confidence values for each node based on 1000 bootstrap replicates (Figure 3 and Figure 4).

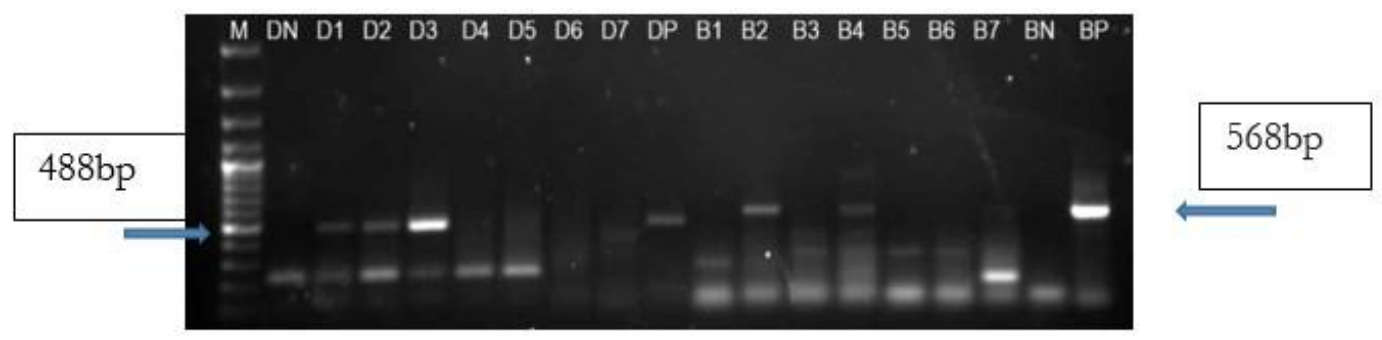

Figure 2. Electrophoresis $P C R$ products of $D W V(D)$ and $B Q C V(B)$ in ants (M. concolor). Lane M: 100bp plus (thermo). Lane DN: DWV negative control. Lane DP: DWV positive control (488 bp). Lane D1-D3: DWV Positive amplification DWV (488 bp). Lane D4-D7: noneamplification DWV. Lane B2, B4: Positive amplification of BQCV (568 bp). Lane B1, B3, B5, B6, B7: none-amplification BQCV. Lane BN: BQCV negative control. Lane BP: BQCV positive control (568 bp) 


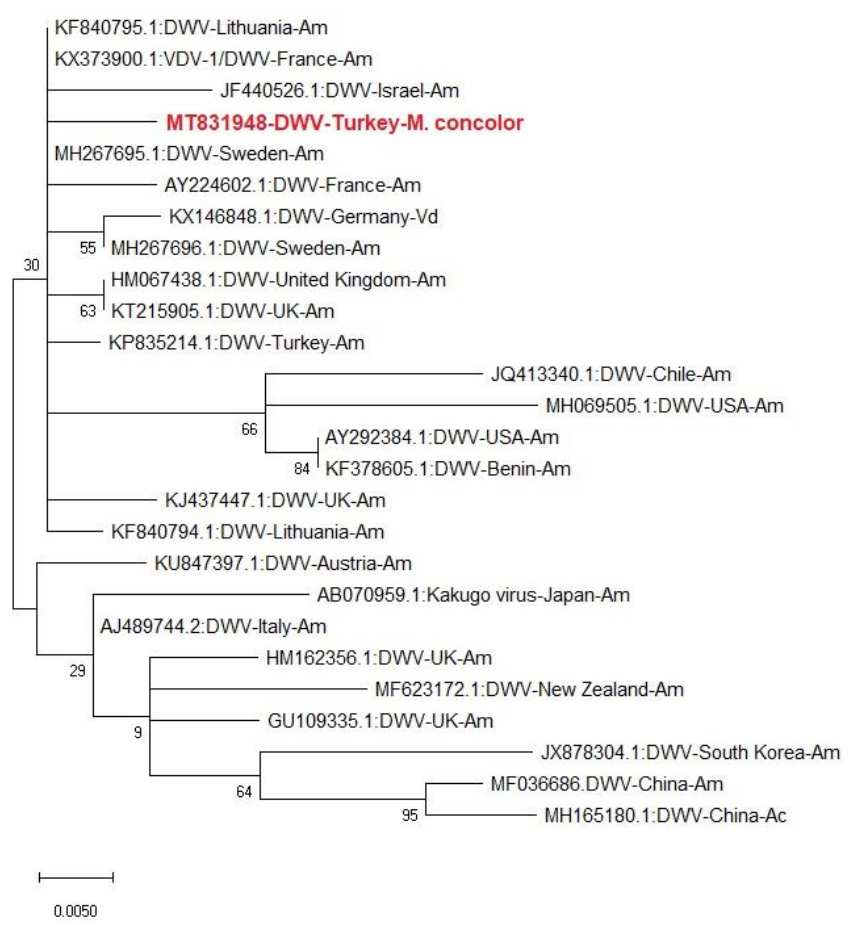

Figure 3. Phylogram of the MT831948-DWV-Turkey-M. concolor isolated based on sequences of polyprotein gene created using the maximum likelihood method in MEGA X. The ratio of correct partition in a 1000-replicate bootstrap analysis can be observed in the statistical base of the nodes. Am = Apis mellifera, Ac = Apis cerana, $V d=$ Varroa destructor

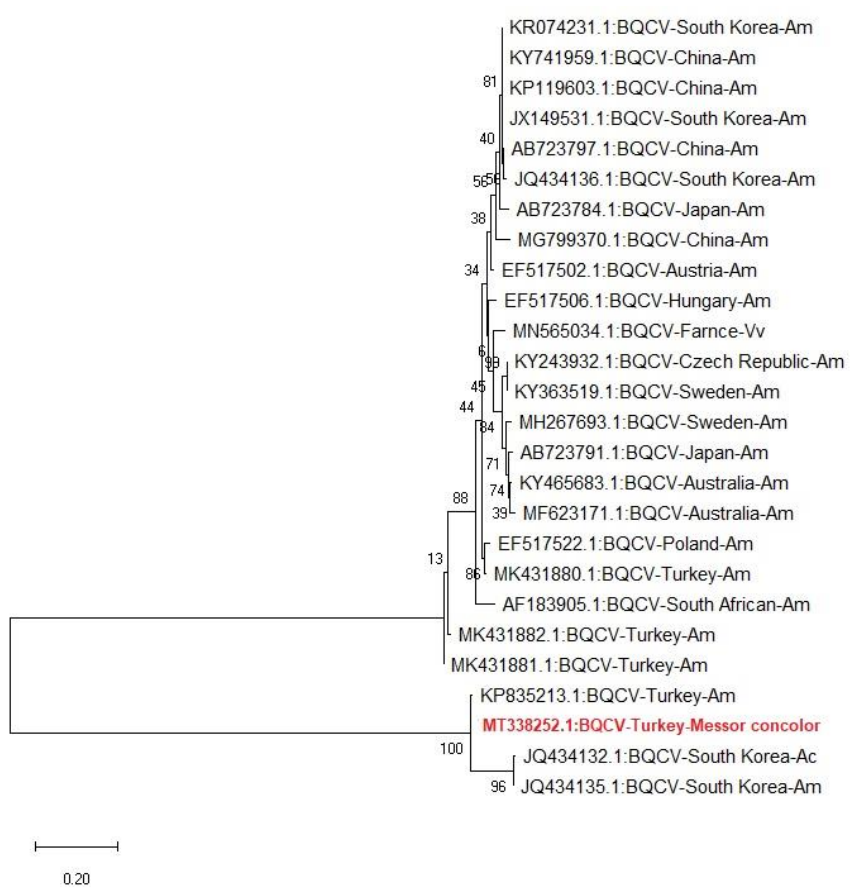

Figure 4. Phylogram of the MT338252.1. BQCV-Turkey-M. concolor isolated based on sequences of Capsid Protein (CP) created using the Maximum likelihood method in MEGA X. The ratio of correct partition in a 1000-replicate bootstrap analysis can be observed in the statistical base of the nodes. Am = Apis mellifera, Ac = Apis cerana, Vv=Vespa velutina 


\section{Discussion}

This study clearly revealed that the isolates of both viruses, BQCV and DWV extracted from same hosts do not cluster (Figures 3 and 4). This may indicate that these two honeybee viruses have not undergone any specific changes to their hosts. The DWV and BQCV sequences obtained from $M$. concolor were mostly identical with nucleotide sequences found $A$. mellifera from same geographic origin.

The earliest bee viruses identified in ants (Camponotus vagus and Formica rufa) was the Chronic bee paralysis virus (CBPV) (Celle et al., 2008), followed by BQCV, DWV, IAPV, and SBV (Levitt et al., 2013). The DWV, BQCV, and KBV were detected in in Argentine ant (Linepithema humile) (Gruber et al., 2017). Lake Sinai viruses (LSV) as a honeybee virus detected in Messor concolor, M. capitatus and M. barbarous (Bigot et al., 2017). ABPV and DWV were detected from the ants (Lasius platythorax) collected from the apiary (Schläppi et al., 2020). Further the efforts on honeybee virus in ants revealed the presence of at least one of the DWV, BQCV, IAPV, ABPV, KBV, and SBV in Brachymyrmex, Forelius, Linepithema, Solenopsis, Nylanderia, Pheidole, Camponotus, Aphaenogaster, Crematogaster, Pogonomyrmex, and Pseudomyrmex ant genera (Payne et al., 2020). BQCV and DWV can infect other Apis species (Apis florea and Apis dorsata) (Zhang et al., 2012), some of bumble bee species (Bombus terrestris, B. pascuorum, B. huntii, B. impatiens, B. vagans, B. ternarius) (Genersch et al., 2006; Singh et al., 2010; Li et al., 2011; Peng et al., 2011), and isolated from the eastern carpenter bee (Xylocopa virginica), mining bees (Andrena sp.), yellow jackets (Vespula vulgaris), and sand wasp (Bembix sp.), pollen pellets from forager bees (Singh et al., 2010). Herein, the existence of DWV and BQCV in M. concolor, a carnivore ant species is reported for the first time.

The phylogenetic analysis showed that viruses isolated from the different host can cluster each other, for both BQCV and DWV, the sequences isolated from the ants clustered together with previous sequences from the A. mellifera. According to the phylogenetic tree, the hosts from the same geographical origin likely cluster each other, and besides during this the survey, it was observed that ants attack the honeybees, especially which have disabilities and cannot enter the hive because of wing deformations. These results suggest that BQCV and DWV might have transmitted from A. mellifera to $M$. concolor. Messor concolor could be another vector of these viruses as a possible spread route. In apiaries, any virus infected organism could pose a danger for honeybee populations especially, the hymenopteran insects sharing same sources with honeybees. On the other hand, since the infected honeybee individuals are dismissed from the hives and preyed by ants, the virus density in hives may reduce. Otherwise, infected honeybee individuals could be a greater threat for hives via conataminating healthy individuals by topical contact (Amiri et al., 2014, 2019; Coulon et al., 2018). Further, the genome variability of a partial sequence of DWV and BQCV were evaluated and it does not appear to be separated by the host, but rather moving between species.

\section{Conclusion}

In summary, this study reports the presence of two significant honeybee infecting virus species, DWV and BQCV from M. concolor, which is carnivore ant species, under natural conditions. These findings suggest that other trophic levels could be involved in spread of honeybee viruses. However, it is not clear how such an involvement could affect honeybee population dynamics. The presence of the honeybee infecting viruses should 
be checked across other arthropod communities around apiaries which could help a better understanding of virus transmission routes.

Acknowledgements. I would like to appreciate the kind help of Dr. Sándor Csősz (California Academy of Sciences, San Francisco, USA) for the identification of ant specimens. This study was financially supported by Şırnak University Research Foundation (Project no: 2017.04.02.01).

\section{REFERENCES}

[1] Allen, M., Ball, B. (1996): The incidence and world distribution of honey bee viruses. Bee world 77(3): 141-162.

[2] Amiri, E., Meixner, M., Büchler, R., Kryger, P. (2014): Chronic Bee paralysis virus in honeybee queens: evaluating susceptibility and infection routes. - Viruses 6: 1188-1201.

[3] Amiri, E., Seddon, G., Zuluaga Smith, W., Strand, M. K., Tarpy, D. R., Rueppell, O. (2019): Israeli acute paralysis virus: honey bee queen-worker interaction and potential virus transmission pathways. - Insects 10: 9 .

[4] Bailey, L., Ball, B. V., Perry, J. N. (1983): Association of viruses with two protozoal pathogens of the honey bee. - Annals of Applied Biology 103(1): 13-20.

[5] Bailey, L., Ball, B. V. (1991): Honey bee pathology. - Academic Press, London.

[6] Berényi, O., Bakonyi, T., Derakhshifar, I., Köglberger, H., Topolska, G., Ritter, W., Pechhacker, H., Nowotny, N. (2007): Phylogenetic analysis of deformed wing virus genotypes from diverse geographic origins indicates recent global distribution of the virus. - Applied and Environmental Microbiology 73(11): 3605-3611.

[7] Bigot, D., Dalmon, A., Roy, B., Hou, C., Germain, M., Romary, M., Deng, S., Diao, Q., Weinert, L., Cook, J. M., Herniou, E. A., Gayral, P. (2017): The discovery of Halictivirus resolves the Sinaivirus phylogeny. - The Journal of general virology 98(11): 2864-2875.

[8] Celle, O., Blanchard, P., Olivier, V., Schurr, F., Cougoule, N., Faucon, J. P., Ribière, M. (2008): Detection of Chronic bee paralysis virus (CBPV) genome and its replicative RNA form in various hosts and possible ways of spread. - Virus Research 133(2): 280-284.

[9] Choi, N. R., Jung, C., Lee, D. W. (2015): Optimization of detection of black queen cell virus from Bombus terrestris via real-time PCR. - Journal of Asia-Pacific Entomology 18(1): 9-12.

[10] Coulon, M., Schurr, F., Martel, A. C., Cougoule, N., Bégaud, A., Mangoni, P., Dalmon, A., Alaux, C., Conte, Y. L., Thiéry, R., Chabert, M. R., Dubois, E. (2018): Metabolisation of thiamethoxam (a neonicotinoid pesticide) and interaction with the Chronic bee paralysis virus in honeybees. - Pesticide Biochemistry and Physiology 144: 10-18.

[11] De Miranda, J. R., Genersch, E. (2010): Deformed wing virus. - Journal of invertebrate pathology 103: 48-61.

[12] De Miranda, J. R., Bailey, L., Ball, B. V., Blanchard, P., Budge, G., Chejanovsky, N., Chen, Y. P., Gauthier, L., Genersch, E., De Graaf, D., Ribière, M., Ryabov, E., De Smet, L., Van Der Steen, J. J. M. (2013): Standard Methods for Virus Research in Apis mellifera. Journal of Apicultural Research 52(4): 1-55.

[13] Ellis, J. D., Munn, P. A. (2005): The worldwide health status of honey bees. - Bee world 86(4): 88-101.

[14] Eyer, M., Chen, Y. P., Schäfer, M. O., Pettis, J., Neumann, P. (2009): Small hive beetle, Aethina tumida, as a potential biological vector of honeybee viruses. - Apidologie 40(4): 419-428.

[15] Foissac, L., Gentit, P., Svanetia-Dumas, L., Dulucq, M. J., Candresse, T. (2001): Polyvalent detection of fruit tree tricho, capillo, and fovea viruses by nested RT-PCR using degenerated and inosine containing primers (PDO RT-PCR). - Acta Hortic 550: 37-43. 
[16] Freiberg, M., De Jong, D., Message, D., Cox-Foster, D. (2012): First report of sacbrood virus in honey bee (Apis mellifera) colonies in Brazil. - Genetics and Molecular Research 11(3): 3310-3314.

[17] Genersch, E., Yue, C., Fries, I., de Miranda, J. R. (2006): Detection of Deformed wing virus, a honey bee viral pathogen, in bumble bees (Bombus terrestris and Bombus pascuorum) with wing deformities. - Journal of invertebrate pathology 91(1): 61-63.

[18] Gruber, M. A. M., Cooling, M., Baty, J. W., Buckley, K., Friedlander, A., Quinn, O., Russell, J. F. E. J., Sébastien, A., Lester, P. J. (2017): Single-stranded RNA viruses infecting the invasive Argentine ant, Linepithema humile. - Scientific reports 7: 3304.

[19] Kumar, S., Stecher, G., Li, M., Knyaz, C., Tamura, K. (2018): MEGA X: Molecular Evolutionary Genetics Analysis across computing platforms. - Molecular Biology and Evolution 35: 1547-1549.

[20] Lanzi, G., De Miranda, J. R., Boniotti, M. B., Cameron, C. E., Lavazza, A., Capucci, L., Capucci, L., Rossi, C. (2006): Molecular and biological characterization of deformed wing virus of honeybees (Apis mellifera L.). - Journal of Virology 80(10): 4998-5009.

[21] Levitt, A. L., Singh, R., Cox-Foster, D. L., Rajotte, E., Hoover, K., Ostiguy, N., Holmes, E. C. (2013): Cross-species transmission of honey bee viruses in associated arthropods. Virus Research 176(1-2): 232-240.

[22] Li, J., Peng, W., Wu, J., Strange, J. P., Boncristiani, H., Chen, Y. (2011): Cross-species infection of deformed wing virus poses a new threat to pollinator conservation. - Journal of Economic Entomology 104(3): 732-739.

[23] McMenamin, A. J., Genersch, E. (2015): Honey bee colony losses and associated viruses. - Current Opinion in Insect Science 8: 121-129.

[24] Payne, A. N., Shepherd, T. F., Rangel, J. (2020): The detection of honey bee (Apis mellifera)-associated viruses in ants. - Scientific reports 10(1): 1-8.

[25] Peng, W., Li, J., Boncristiani, H., Strange, J. P., Hamilton, M., Chen, Y. (2011): Host range expansion of honey bee Black Queen Cell Virus in the bumble bee, Bombus huntii. Apidologie 42(5): 650-658.

[26] Rüstemoğlu, M., Sipahioğlu, H. M. (2019): Occurrence and Prevalence of Six Honey Bee Viruses in Hakkari (Turkey) and Their Genomic Divergence. - Munis Entomology \& Zoology 14(2): 574-583.

[27] Sambrook, J., Fritsch, E. F., Maniatis, T. (1989): Molecular cloning: a laboratory manual. - Cold spring harbor laboratory press.

[28] Schläppi, D., Lattrell, P., Yañez, O., Chejanovsky, N., Neumann, P. (2019): Foodborne Transmission of Deformed Wing Virus to Ants (Myrmica rubra). - Insects 10(11): 394.

[29] Schläppi, D., Chejanovsky, N., Yañez, O., Neumann, P. (2020): Foodborne transmission and clinical symptoms of honey bee viruses in ants Lasius spp. - Viruses 12: 321. doi: 10.3390/v120 30321.

[30] Singh, R., Levitt, A. L., Rajotte, E. G., Holmes, E. C., Ostiguy, N., van Engelsdorp, D., Lipkin, W. I., dePamphilis, C. W., Toth, A. L., Cox-Foster, D. L. (2010): RNA viruses in hymenopteran pollinators: evidence of inter-taxa virus transmission via pollen and potential impact on non-Apis hymenopteran species. - PloS one 5(12): e14357.

[31] Smith, K. M., Loh, E. H., Rostal, M. K., Zambrana-Torrelio, C. M., Mendiola, L., Daszak, P. (2013): Pathogens, pests, and economics: drivers of honey bee colony declines and losses. - EcoHealth 10(4): 434-445.

[32] Tamura, K., Nei, M. (1993): Estimation of the number of nucleotide substitutions in the control region of mitochondrial DNA in humans and chimpanzees. - Molecular Biology and Evolution 10: 512-526.

[33] Tapaszti, Z., Forgách, P., Kővágó, C., Topolska, G., Nowotny, N., Rusvai, M., Bakonyi, T. (2009): Genetic analysis and phylogenetic comparison of Black queen cell virus genotypes. - Veterinary microbiology 139(3-4): 227-234. 
[34] Traiyasut, P., Mookhploy, W., Kimura, K., Yoshiyama, M., Khongphinitbunjong, K., Chantawannakul, P. (2016): First detection of honey bee viruses in wax moth. - Chiang Mai University Journal of Natural Sciences 43: 695-698.

[35] Zhang, X., He, S. Y., Evans, J. D., Pettis, J. S., Yin, G. F., Chen, Y. P. (2012): New evidence that deformed wing virus and black queen cell virus are multi-host pathogens. - Journal of Invertebrate Pathology 109(1): 156-159. 